\title{
Thermal Decomposition Kinetics of Aged Solid Propellant Based on Ammonium Perchlorate - AP/HTPB Binder
}

\author{
R. F. B. Gonçalves, J. A. F. F. Rocco and K. Iha \\ Additional information is available at the end of the chapter
}

http://dx.doi.org/10.5772/52109

\section{Introduction}

Despite the widespread use and long investigative history of ammonium perchlorate(AP)fuel mixtures, it still can be said that AP alone and AP/HTPB (hydroxyl-terminatedpolybutadiene) composites remain among the most confounding materials in the research setting [1]. Since the physical structure of composite propellants like the AP/HTPB composite is heterogeneous, the combustion wave structure appears to be also heterogeneous. During the combustion, at the burning surface, the decomposed gases from the ammonium perchlorate particles and fuel binder (HTPB) are interdiffused and produce diffusion flame streams. Due this, the flame structure of AP composite propellants is complex and locally three-dimensional in shape.

Ammonium perchlorate $\left(\mathrm{NH}_{4} \mathrm{ClO}_{4}\right)$ is a powerful oxidizer salt largely used in solid propellant formulations for application in airspace and defense materials industries. It is obtained by reaction between ammonia and perchloric acid, or by double decomposition between an ammonium salt and sodium perchlorate, and crystallizes with romboedric structure in room temperature and pressure, with relative density of 1.95 [2] Similarly to most ammonium salts, AP thermal decomposition occurs before its fusion. When submitted to a low heating rate, decomposes releasing gases chlorine, nitrogen and oxygen and water in the vapor state; while with a high heating rate stimulus there are instant reactions with high energy release.

During the combustion process of AP crystals at high pressures, is possible to observe the formation of a tiny layer of ammonium perchlorate in liquid phase at the grain surface [3], followed by a region where it is presented in gaseous phase. 
According to Beckstead and Puduppakkam [4], the combustion of a monopropellant can be divided in three regions (condensed, liquid-gas two-phase region and gas region). The twophase region consists of liquid and gaseous species resulting from the melting and/or decomposition of the solid phase. The precise division between the two-phase and gasphase region (i.e. the 'burning surface') is not well defined due to chemical reactions, bubbles, and condensed material being convected away from the surface. In the gas phase region of a monopropellant, the flame is essentially premixed. The species emanating from the surface react with each other and/or decompose to form other species. A wide variety of reactions involving many species occur in the gas flame until equilibrium is reached in the final flame zone.

Thermal decomposition of AP, as its combustion processes, have been experimentally studied and reported in the literature. The thermal decomposition of AP may be observed by differential thermal analysis (DTA) and thermal gravimetry (TG), in the figure below [5]. A heating rate of $0.33 \mathrm{~K} / \mathrm{s}$ was used on the analysis.

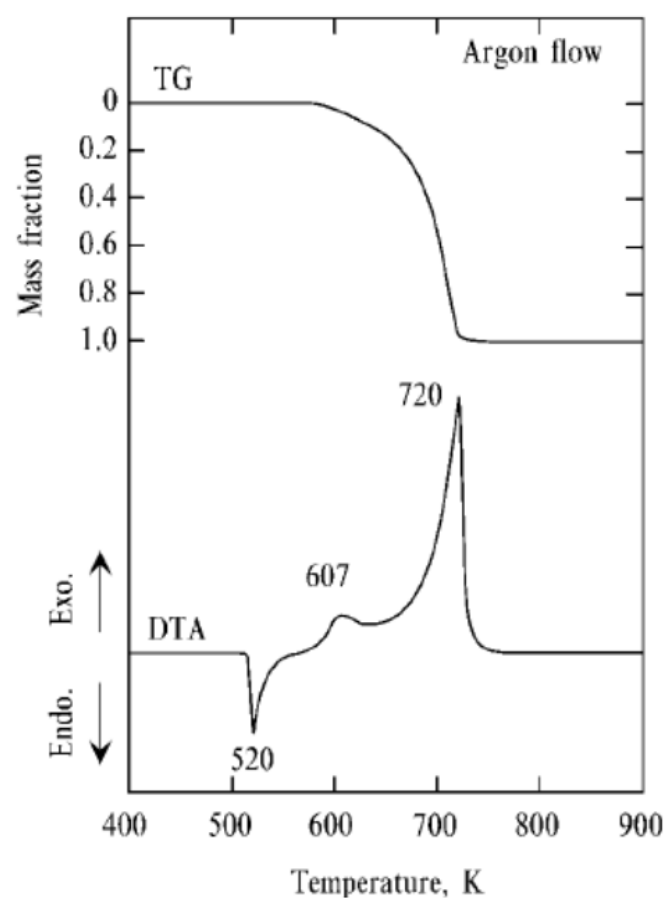

Figure 1. TG and DTA of AP decomposition [5]

The phase transition from orthorhombic to cubic crystal lattice $(\Delta \mathrm{H}=-85 \mathrm{~kJ} / \mathrm{kg})$ is represented by the endothermic peak on $520 \mathrm{~K}$. The exothermic events on $607 \mathrm{~K}$ and $720 \mathrm{~K}$ are due to the proper decomposition of the AP crystal in ammonia and perchloric acid, followed by the formation of chloridric acid and oxygen (decomposition of $\mathrm{HClO}_{4}$ ), according to the reactions below. 


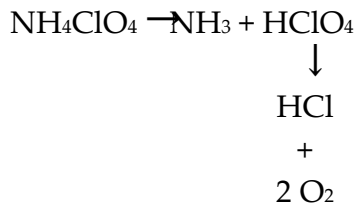

These oxygen molecules will be used as oxidizer in binders combustion, when the AP is used in a composite propellant or even when is burning by itself.

The combustion mechanism of AP has been studied and modified. The table below shows the elementary reactions which take part on the combustion process. This mechanism was proposed by Gross [6], according to literature data. It is very interesting the analysis of the combustion for its close relation to the thermal decomposition. When high pressure or high temperatures are used, the material suffers combustion instead of thermal decomposition, i.e. there's a higher velocity of decomposition and higher energy release, but the process is usually incomplete.

\begin{tabular}{|c|c|c|c|}
\hline Reaction & A & $\mathbf{b}$ & Ea \\
\hline $\mathrm{HClO}_{4}=\mathrm{ClO}_{3}+\mathrm{OH}$ & $1.00 \mathrm{E}+14$ & 0.0 & $3.91 \mathrm{E}+04$ \\
\hline $\mathrm{HClO}_{4}+\mathrm{HNO}=\mathrm{ClO}_{3}+\mathrm{H}_{2} \mathrm{O}+\mathrm{NO}$ & $1.50 \mathrm{E}+13$ & 0.0 & $6.00 \mathrm{E}+03$ \\
\hline $\mathrm{ClO}_{3}=\mathrm{ClO}+\mathrm{O}_{2}$ & $1.70 \mathrm{E}+13$ & 0.5 & $0,00 \mathrm{E}+00$ \\
\hline $\mathrm{Cl}_{2}+\mathrm{O}_{2}+\mathrm{M}=\mathrm{ClO}_{2}+\mathrm{Cl}+\mathrm{M}$ & $6.00 \mathrm{E}+08$ & 0.0 & $1.12 \mathrm{E}+04$ \\
\hline $\mathrm{ClO}+\mathrm{NO}=\mathrm{Cl}+\mathrm{NO}_{2}$ & $6.78 \mathrm{E}+12$ & 0.0 & $3.11 \mathrm{E}+02$ \\
\hline $\mathrm{ClO}+\mathrm{ClOH}=\mathrm{Cl}_{2}+\mathrm{HO}_{2}$ & $1.00 \mathrm{E}+11$ & 0.0 & $1.00 \mathrm{E}+04$ \\
\hline $\mathrm{ClOH}+\mathrm{OH}=\mathrm{ClO}+\mathrm{H}_{2} \mathrm{O}$ & $1.80 \mathrm{E}+13$ & 0.0 & $0,00 \mathrm{E}+00$ \\
\hline $\mathrm{HCl}+\mathrm{OH}=\mathrm{Cl}+\mathrm{H}_{2} \mathrm{O}$ & $5.00 \mathrm{E}+11$ & 0.0 & $7.50 \mathrm{E}+02$ \\
\hline $\mathrm{Cl}_{2}+\mathrm{H}=\mathrm{HCl}+\mathrm{Cl}$ & $8.40 \mathrm{E}+13$ & 0.0 & $1.15 \mathrm{E}+03$ \\
\hline $\mathrm{ClO}+\mathrm{NH}_{3}=\mathrm{ClOH}+\mathrm{NH}_{2}$ & $6.00 \mathrm{E}+11$ & 0.5 & $6.40 \mathrm{E}+03$ \\
\hline $\mathrm{NH}_{3}+\mathrm{Cl}=\mathrm{NH}_{2}+\mathrm{HCl}$ & $4.50 \mathrm{E}+11$ & 0.5 & $1.00 \mathrm{E}+02$ \\
\hline $\mathrm{NH}_{3}+\mathrm{OH}=\mathrm{NH}_{2}+\mathrm{H} 2 \mathrm{O}$ & $5.00 \mathrm{E}+07$ & 1.6 & $9.55 \mathrm{E}+02$ \\
\hline $\mathrm{NH}_{2}+\mathrm{O}_{2}=\mathrm{HNO}+\mathrm{OH}$ & $3.00 \mathrm{E}+09$ & 0.0 & $0,00 \mathrm{E}+00$ \\
\hline $\mathrm{NH}_{2}+\mathrm{NO}=\mathrm{H}_{2} \mathrm{O}+\mathrm{N}_{2}$ & $6.20 \mathrm{E}+15$ & -1.3 & $0,00 \mathrm{E}+00$ \\
\hline $\mathrm{HNO}+\mathrm{OH}=\mathrm{NO}+\mathrm{H}_{2} \mathrm{O}$ & $1.30 \mathrm{E}+07$ & 1.9 & $-9.50 \mathrm{E}+02$ \\
\hline $\mathrm{HNO}+\mathrm{O}_{2}=\mathrm{NO}_{2}+\mathrm{OH}$ & $1.50 \mathrm{E}+13$ & 0.0 & $1.00 \mathrm{E}+04$ \\
\hline $\mathrm{HNO}+\mathrm{H}=\mathrm{H}_{2}+\mathrm{NO}$ & $4.50 \mathrm{E}+11$ & 0.7 & $6.60 \mathrm{E}+02$ \\
\hline $\mathrm{NO}+\mathrm{H}+\mathrm{M}=\mathrm{HNO}+\mathrm{M}$ & $8.90 \mathrm{E}+19$ & -1.3 & $7.40 \mathrm{E}+02$ \\
\hline $\mathrm{HO}_{2}+\mathrm{N}_{2}=\mathrm{HNO}+\mathrm{NO}$ & $2.70 \mathrm{E}+10$ & 0.5 & $4.18 \mathrm{E}+04$ \\
\hline $\mathrm{NO}+\mathrm{HO}_{2}=\mathrm{NO}_{2}+\mathrm{OH}$ & $2.11 \mathrm{E}+12$ & 0.0 & $4.80 \mathrm{E}+02$ \\
\hline $\mathrm{H}+\mathrm{NO}_{2}=\mathrm{NO}+\mathrm{OH}$ & $3.47 \mathrm{E}+14$ & 0.0 & $1.48 \mathrm{E}+03$ \\
\hline $\mathrm{H}_{2}+\mathrm{OH}=\mathrm{H}_{2} \mathrm{O}+\mathrm{H}$ & $2.16 \mathrm{E}+08$ & 1.5 & $3.43 E+03$ \\
\hline
\end{tabular}

Table 1. AP combustion mechanism $k=A T^{b} \exp (-E / R T)$. Units: $A$ (mol-cm-s-K), $E(\mathrm{~J} / \mathrm{mol})$. 
Based on combustion mechanisms, the burning process may be simulated and analyzed by some specific softwares. In a previous work [7], these simulations were done, considering a perfectly stirred reactor, different internal pressures and a specific temperature profile. The combustion simulation results may be observed in the figure below, which show the behavior of AP combustion with different internal pressures of the combustion chamber.
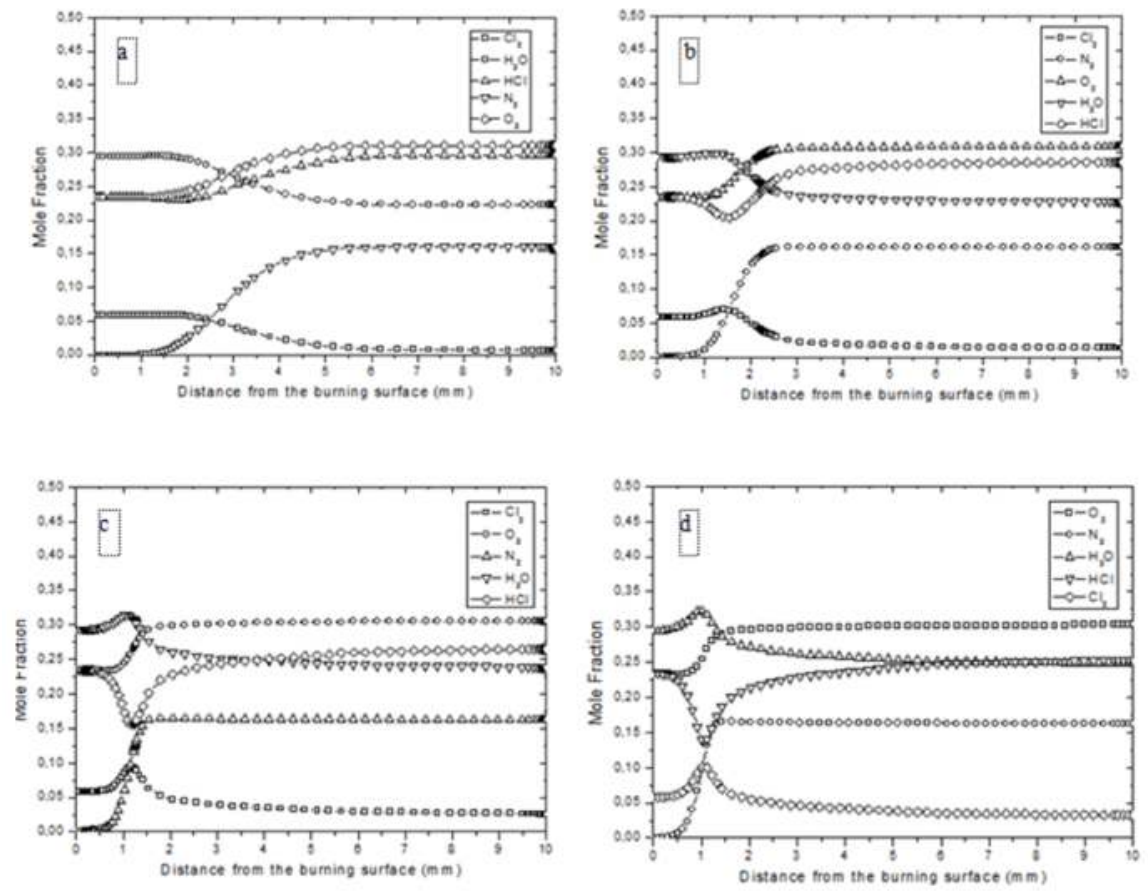

Figure 2. AP combustion at a) 1 atm; b) 5 atm; c) 30 atm and d) 60 atm.

The "elbows" appear due to the increase of the occurrence of intermediate reactions in the flame zone. This phenomenon generates a great variation on the mole fractions of intermediates (as the high temperature enhance the speed of the slower reactions, generating more radicals), which modify the concentration of the main species (specially in the flame zone), so the different slope is observed. As the pressure in the combustion chamber increases, there is an approximation of the flame to the material's surface and accentuation of the "elbows" presented on the flame region, indicating the influence of the speed increase of elementary reactions in the decomposition process of the material in study. This gain in chemical speed reactions may be converted in gain in thrust of rocket motors and specific impulse of solid propellant grains.

When a composite propellant is used, like AP-HTPB, the combustion process depends on the diffusion of the gases generated on the initial decomposition of the oxidizer, which surrounds the binder molecules at the burning surface. The combustion mechanism has higher complexity as new components are added, because there are the elementary reactions 
for each component decomposition and their interactions in chamber, as well as the formation and decomposition of new intermediary species, especially in the flame region. The proposed mechanism for AP-HTPB combustion may be observed in Table 2 below.

\begin{tabular}{|c|c|c|c|}
\hline Reaction & $\mathrm{A}$ & $\mathrm{b}$ & $\mathrm{Ea}$ \\
\hline $\mathrm{Cl}_{2}+\mathrm{O}_{2}+\mathrm{M}=\mathrm{ClO}_{2}+\mathrm{Cl}+\mathrm{M}$ & $6.00 \mathrm{E}+08$ & 0 & $1.12 \mathrm{E}+04$ \\
\hline $\mathrm{ClO}+\mathrm{NO}=\mathrm{Cl}+\mathrm{NO}_{2}$ & $6.78 \mathrm{E}+12$ & 0 & $3.11 \mathrm{E}+02$ \\
\hline $\mathrm{HCl}+\mathrm{OH}=\mathrm{Cl}+\mathrm{H}_{2} \mathrm{O}$ & $5.00 \mathrm{E}+11$ & 0 & $7.50 \mathrm{E}+02$ \\
\hline $\mathrm{Cl}_{2}+\mathrm{H}=\mathrm{HCl}+\mathrm{Cl}$ & $8.40 \mathrm{E}+13$ & 0 & $1.15 E+03$ \\
\hline $\mathrm{NH}_{3}+\mathrm{Cl}=\mathrm{NH}_{2}+\mathrm{HCl}$ & $4.50 \mathrm{E}+11$ & 0.5 & $1.00 \mathrm{E}+02$ \\
\hline $\mathrm{NH}_{3}+\mathrm{OH}=\mathrm{NH}_{2}+\mathrm{H}_{2} \mathrm{O}$ & $5.00 \mathrm{E}+07$ & 1.6 & $9.55 \mathrm{E}+02$ \\
\hline $\mathrm{NH}_{2}+\mathrm{O}_{2}=\mathrm{HNO}+\mathrm{OH}$ & $3.00 \mathrm{E}+09$ & 0 & $0.00 \mathrm{E}+00$ \\
\hline $\mathrm{NH}_{2}+\mathrm{NO}=\mathrm{H}_{2} \mathrm{O}+\mathrm{N}_{2}$ & $6.20 \mathrm{E}+15$ & -1.3 & $0.00 \mathrm{E}+00$ \\
\hline $\mathrm{HNO}+\mathrm{OH}=\mathrm{NO}+\mathrm{H}_{2} \mathrm{O}$ & $1.30 \mathrm{E}+07$ & 1.9 & $-9.50 E+02$ \\
\hline $\mathrm{HNO}+\mathrm{O}_{2}=\mathrm{NO}_{2}+\mathrm{OH}$ & $1.50 \mathrm{E}+13$ & 0 & $1.00 \mathrm{E}+04$ \\
\hline $\mathrm{HNO}+\mathrm{H}=\mathrm{H}_{2}+\mathrm{NO}$ & $4.50 \mathrm{E}+11$ & 0.7 & $6.60 \mathrm{E}+02$ \\
\hline $\mathrm{NO}+\mathrm{H}+\mathrm{M}=\mathrm{HNO}+\mathrm{M}$ & $8.90 \mathrm{E}+19$ & -1.3 & $7.40 \mathrm{E}+02$ \\
\hline $\mathrm{HO}_{2}+\mathrm{N}_{2}=\mathrm{HNO}+\mathrm{NO}$ & $2.70 \mathrm{E}+10$ & 0.5 & $4.18 \mathrm{E}+04$ \\
\hline $\mathrm{NO}+\mathrm{HO}_{2}=\mathrm{NO}_{2}+\mathrm{OH}$ & $2.11 \mathrm{E}+12$ & 0 & $4.80 \mathrm{E}+02$ \\
\hline $\mathrm{H}+\mathrm{NO}_{2}=\mathrm{NO}+\mathrm{OH}$ & $3.47 \mathrm{E}+14$ & 0 & $1.48 \mathrm{E}+03$ \\
\hline $\mathrm{H}_{2}+\mathrm{OH}=\mathrm{H}_{2} \mathrm{O}+\mathrm{H}$ & $2.16 \mathrm{E}+08$ & 1.5 & $3.43 \mathrm{E}+03$ \\
\hline $\mathrm{CH}_{4}+\mathrm{Cl}=\mathrm{CH}_{3}+\mathrm{HCl}$ & $2.50 \mathrm{E}+13$ & 0 & $3.83 \mathrm{E}+03$ \\
\hline $\mathrm{CH}_{4}+\mathrm{H}=\mathrm{CH}_{3}+\mathrm{H}_{2}$ & $6.60 \mathrm{E}+08$ & 1.6 & $1.08 \mathrm{E}+04$ \\
\hline $\mathrm{CH}_{4}+\mathrm{OH}=\mathrm{CH}_{3}+\mathrm{H}_{2} \mathrm{O}$ & $1.00 \mathrm{E}+08$ & 1.6 & $3.12 E+03$ \\
\hline $\mathrm{CH}_{3}+\mathrm{H}+\mathrm{M}=\mathrm{CH}_{4}+\mathrm{M}$ & $1.27 \mathrm{E}+16$ & -0.6 & $3.83 E+02$ \\
\hline $\mathrm{CO}+\mathrm{OH}=\mathrm{CO}_{2}+\mathrm{H}$ & $4.76 \mathrm{E}+07$ & 1.2 & $7.00 \mathrm{E}+01$ \\
\hline $\mathrm{CO}+\mathrm{ClO}=\mathrm{CO}_{2}+\mathrm{Cl}$ & $3.00 \mathrm{E}+12$ & 0 & $1.00 \mathrm{E}+03$ \\
\hline $\mathrm{CO}+\mathrm{ClO}_{2}=\mathrm{CO}_{2}+\mathrm{ClO}$ & $1.00 \mathrm{E}+10$ & 0 & $0.00 \mathrm{E}+00$ \\
\hline $\mathrm{H}+\mathrm{O}_{2}=\mathrm{O}+\mathrm{OH}$ & $8.30 \mathrm{E}+13$ & 0 & $1.44 \mathrm{E}+04$ \\
\hline $\mathrm{CH}_{2}+\mathrm{H}_{2}=\mathrm{CH}_{3}+\mathrm{H}$ & $5.00 \mathrm{E}+05$ & 2 & $7.23 \mathrm{E}+03$ \\
\hline $\mathrm{CH}_{2}+\mathrm{H}+\mathrm{M}=\mathrm{CH}_{3}+\mathrm{M}$ & $2.50 \mathrm{E}+16$ & -0.8 & $0.00 \mathrm{E}+00$ \\
\hline $\mathrm{CH}_{4}+\mathrm{O}=\mathrm{CH}_{3}+\mathrm{OH}$ & $1.02 \mathrm{E}+09$ & 1.5 & $6.00 \mathrm{E}+02$ \\
\hline $\mathrm{OH}+\mathrm{CH}_{3}=\mathrm{CH}_{2}+\mathrm{H}_{2} \mathrm{O}$ & $5.60 \mathrm{E}+07$ & 1.6 & $5.42 \mathrm{E}+03$ \\
\hline $\mathrm{C}_{2} \mathrm{H}_{4}+\mathrm{O}_{2}=2 \mathrm{CO}+2 \mathrm{H}_{2}$ & $1.80 \mathrm{E}+14$ & 0 & $3.55 \mathrm{E}+04$ \\
\hline $\mathrm{NH}_{2}+\mathrm{NO}_{2}=2 \mathrm{HNO}$ & $1.40 \mathrm{E}+12$ & 0 & $0.00 \mathrm{E}+00$ \\
\hline $\mathrm{NH}_{2}+\mathrm{ClO}=\mathrm{HNO}+\mathrm{HCl}$ & $2.50 \mathrm{E}+12$ & 0 & $0.00 \mathrm{E}+00$ \\
\hline $\mathrm{O}_{2}+\mathrm{HNO}=\mathrm{NO}+\mathrm{HO}_{2}$ & $1.00 \mathrm{E}+13$ & 0 & $1.30 \mathrm{E}+04$ \\
\hline $\mathrm{H}+\mathrm{Cl}+\mathrm{M}=\mathrm{HCl}+\mathrm{M}$ & $5.30 \mathrm{E}+21$ & -2 & $-2.00 \mathrm{E}+03$ \\
\hline $\mathrm{Cl}+\mathrm{Cl}+\mathrm{M}=\mathrm{Cl}_{2}+\mathrm{M}$ & $3.34 \mathrm{E}+14$ & 0 & $-1.80 \mathrm{E}+03$ \\
\hline $\mathrm{Cl}+\mathrm{HO}_{2}=\mathrm{ClO}+\mathrm{OH}$ & $2.47 \mathrm{E}+13$ & 0 & $8.94 \mathrm{E}+02$ \\
\hline $\mathrm{ClO}+\mathrm{O}=\mathrm{Cl}+\mathrm{O}_{2}$ & $6.60 \mathrm{E}+13$ & 0 & $4.40 \mathrm{E}+02$ \\
\hline $\mathrm{H}+\mathrm{HCl}=\mathrm{Cl}+\mathrm{H}_{2}$ & $7.94 \mathrm{E}+12$ & 0 & $3.40 \mathrm{E}+03$ \\
\hline $\mathrm{HCl}+\mathrm{O}=\mathrm{Cl}+\mathrm{OH}$ & $2.30 \mathrm{E}+11$ & 0.6 & $9.00 \mathrm{E}+02$ \\
\hline
\end{tabular}




\begin{tabular}{|c|c|c|c|}
\hline $\mathrm{Cl}_{2}+\mathrm{O}=\mathrm{Cl}+\mathrm{ClO}$ & $2.51 \mathrm{E}+12$ & 0 & $2.72 \mathrm{E}+03$ \\
\hline $\mathrm{N}_{2} \mathrm{O}+\mathrm{M}=\mathrm{N}_{2}+\mathrm{O}+\mathrm{M}$ & $6.20 \mathrm{E}+14$ & 0 & $5.61 \mathrm{E}+04$ \\
\hline $\mathrm{N}_{2} \mathrm{O}+\mathrm{OH}=\mathrm{N}_{2}+\mathrm{HO}_{2}$ & $2.00 \mathrm{E}+12$ & 0 & $2.11 \mathrm{E}+04$ \\
\hline $\mathrm{N}_{2} \mathrm{O}+\mathrm{O}=\mathrm{NO}+\mathrm{NO}$ & $2.90 \mathrm{E}+13$ & 0 & $2.32 \mathrm{E}+04$ \\
\hline $\mathrm{N}_{2} \mathrm{O}+\mathrm{O}=\mathrm{N}_{2}+\mathrm{O}_{2}$ & $1.40 \mathrm{E}+12$ & 0 & $1.08 \mathrm{E}+04$ \\
\hline $\mathrm{N}_{2} \mathrm{O}+\mathrm{H}=\mathrm{N}_{2}+\mathrm{OH}$ & $4.40 \mathrm{E}+14$ & 0 & $1.89 \mathrm{E}+04$ \\
\hline $2 \mathrm{H}+\mathrm{M}<=>\mathrm{H}_{2}+\mathrm{M}$ & $1.00 \mathrm{E}+18$ & -1 & $0.00 \mathrm{E}+00$ \\
\hline $2 \mathrm{H}+\mathrm{H}_{2}<=>2 \mathrm{H}_{2}$ & $9.00 \mathrm{E}+16$ & -0.6 & $0.00 \mathrm{E}+00$ \\
\hline $2 \mathrm{H}+\mathrm{H}_{2} \mathrm{O}<\Rightarrow \mathrm{H}_{2}+\mathrm{H}_{2} \mathrm{O}$ & $6.00 \mathrm{E}+19$ & -1.3 & $0.00 \mathrm{E}+00$ \\
\hline $2 \mathrm{H}+\mathrm{CO}_{2}<=>\mathrm{H}_{2}+\mathrm{CO}_{2}$ & $5.50 \mathrm{E}+20$ & -2 & $0.00 \mathrm{E}+00$ \\
\hline $\mathrm{ClO}_{2}+\mathrm{NO}=\mathrm{ClO}+\mathrm{NO}_{2}$ & $1.00 \mathrm{E}+11$ & 0 & $0.00 \mathrm{E}+00$ \\
\hline $\mathrm{Cl}+\mathrm{ClO}_{2}=\mathrm{ClO}+\mathrm{ClO}$ & $5.00 \mathrm{E}+13$ & 0 & $6.00 \mathrm{E}+03$ \\
\hline $\mathrm{ClO}+\mathrm{ClO}=\mathrm{Cl}_{2}+\mathrm{O}_{2}$ & $1.00 \mathrm{E}+11$ & 0 & $0.00 \mathrm{E}+00$ \\
\hline $\mathrm{Cl}+\mathrm{HO}_{2}=\mathrm{HCl}+\mathrm{O}_{2}$ & $1.80 \mathrm{E}+13$ & 0 & $0.00 \mathrm{E}+00$ \\
\hline $\mathrm{Cl}+\mathrm{O}_{2}+\mathrm{M}=\mathrm{ClO}_{2}+\mathrm{M}$ & $8.00 \mathrm{E}+06$ & 0 & $5.20 \mathrm{E}+03$ \\
\hline $\mathrm{NO}_{2}+\mathrm{O}=\mathrm{NO}+\mathrm{O}_{2}$ & $1.00 \mathrm{E}+13$ & 0 & $6.00 \mathrm{E}+02$ \\
\hline $\mathrm{HNO}+\mathrm{HNO}=\mathrm{H}_{2} \mathrm{O}+\mathrm{N}_{2} \mathrm{O}$ & $3.95 \mathrm{E}+12$ & 0 & $5.00 \mathrm{E}+03$ \\
\hline $\mathrm{NO}_{2}+\mathrm{NO}_{2}=\mathrm{NO}+\mathrm{NO}+\mathrm{O}_{2}$ & $1.00 \mathrm{E}+14$ & 0 & $2.50 \mathrm{E}+04$ \\
\hline $\mathrm{Cl}+\mathrm{N}_{2} \mathrm{O}=\mathrm{ClO}+\mathrm{N}_{2}$ & $1.20 \mathrm{E}+14$ & 0 & $3.35 \mathrm{E}+04$ \\
\hline $\mathrm{OH}+\mathrm{OH}=\mathrm{H}_{2} \mathrm{O}+\mathrm{O}$ & $6.00 \mathrm{E}+08$ & 1.3 & $0.00 \mathrm{E}+00$ \\
\hline $\mathrm{NH}_{2}+\mathrm{NO}_{2}=\mathrm{H}_{2} \mathrm{O}+\mathrm{N}_{2} \mathrm{O}$ & $4.50 \mathrm{E}+11$ & 0 & $0.00 \mathrm{E}+00$ \\
\hline $\mathrm{HNO}+\mathrm{NH}_{2}=\mathrm{NH}_{3}+\mathrm{NO}$ & $5.00 \mathrm{E}+11$ & 0.5 & $1.00 \mathrm{E}+03$ \\
\hline $\mathrm{ClO}+\mathrm{HNO}=\mathrm{HCl}+\mathrm{NO}_{2}$ & $3.00 \mathrm{E}+12$ & 0 & $0.00 \mathrm{E}+00$ \\
\hline $\mathrm{HCl}+\mathrm{HO}_{2}=\mathrm{ClO}+\mathrm{H} 2 \mathrm{O}$ & $3.00 \mathrm{E}+12$ & 0 & $0.00 \mathrm{E}+00$ \\
\hline $\mathrm{NH}_{2}+\mathrm{NO}=\mathrm{H}+\mathrm{N}_{2}+\mathrm{OH}$ & $6.30 \mathrm{E}+19$ & -2.5 & $1.90 \mathrm{E}+03$ \\
\hline $\mathrm{NH}_{2}+\mathrm{OH}=\mathrm{H}_{2} \mathrm{O}+\mathrm{NH}$ & $4.00 \mathrm{E}+06$ & 2 & $1.00 \mathrm{E}+03$ \\
\hline $\mathrm{NH}_{2}+\mathrm{NH}_{2}=\mathrm{NH}+\mathrm{NH}_{3}$ & $5.00 \mathrm{E}+13$ & 0 & $1.00 \mathrm{E}+04$ \\
\hline $\mathrm{NH}+\mathrm{NO}=\mathrm{N}_{2}+\mathrm{OH}$ & $1.00 \mathrm{E}+13$ & 0 & $0.00 \mathrm{E}+00$ \\
\hline $\mathrm{NH}+\mathrm{NO}=\mathrm{H}+\mathrm{N}_{2}+\mathrm{O}$ & $2.30 \mathrm{E}+13$ & 0 & $0.00 \mathrm{E}+00$ \\
\hline $\mathrm{Cl}+\mathrm{NH}_{2}=\mathrm{HCl}+\mathrm{NH}$ & $5.00 \mathrm{E}+10$ & 0.5 & $0.00 \mathrm{E}+00$ \\
\hline $\mathrm{ClO}_{2}+\mathrm{NH}=\mathrm{ClO}+\mathrm{HNO}$ & $1.00 \mathrm{E}+14$ & 0 & $0.00 \mathrm{E}+00$ \\
\hline $\mathrm{N}+\mathrm{NO}_{2}=\mathrm{NO}+\mathrm{NO}$ & $1.00 \mathrm{E}+14$ & 0 & $0.00 \mathrm{E}+00$ \\
\hline $\mathrm{N}+\mathrm{N}_{2} \mathrm{O}=\mathrm{N}_{2}+\mathrm{NO}$ & $5.00 \mathrm{E}+13$ & 0 & $0.00 \mathrm{E}+00$ \\
\hline $\mathrm{NH}+\mathrm{OH}=\mathrm{H}_{2} \mathrm{O}+\mathrm{N}$ & $5.00 \mathrm{E}+11$ & 0.5 & $2.00 \mathrm{E}+03$ \\
\hline $\mathrm{NH}+\mathrm{OH}=\mathrm{H}_{2}+\mathrm{NO}$ & $1.60 \mathrm{E}+12$ & 0.6 & $1.50 \mathrm{E}+03$ \\
\hline $\mathrm{NH}+\mathrm{NH}_{2}=\mathrm{N}+\mathrm{NH}_{3}$ & $1.00 \mathrm{E}+13$ & 0 & $2.00 \mathrm{E}+03$ \\
\hline $\mathrm{HO}_{2}+\mathrm{CH}_{3} \Leftrightarrow=\mathrm{O}_{2}+\mathrm{CH}_{4}$ & $1.00 \mathrm{E}+12$ & 0 & $0.00 \mathrm{E}+00$ \\
\hline $\mathrm{CH}_{2}+\mathrm{CH}_{4} \Leftrightarrow=2 \mathrm{CH}_{3}$ & $2.46 \mathrm{E}+06$ & 2 & $8.27 \mathrm{E}+03$ \\
\hline
\end{tabular}

Table 2. AP-HTPB combustion mechanisma

$$
k=A T^{b} \exp (-E / R T) \text {. Units: } A \text { (mol-cm-s-K), } E(\mathrm{~J} / \mathrm{mol}) .
$$

M: any metal surface or metallic additive used only as support or catalyst

${ }^{a}$ Kinetic data composed of [8] 
Similarly, the combustion process of ammonium perchlorate formulated with hydroxyl terminated polybutadiene was simulated in a perfect stirred reactor (with 70/30 proportion), with variations in the internal chamber pressure (Figure 3 below).

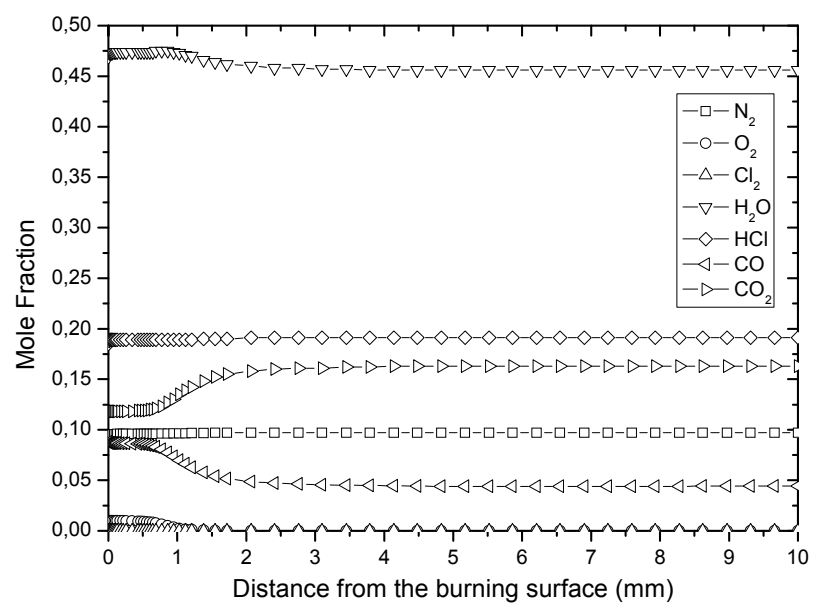

Figure 3. AP/HTPB combustion [7]

The combustion process of AP/HTPB has presented invariable with pressure. This behavior should be attributed to the homogeneous dispersion of AP admist the binder, in the solid phase, and to the lack of this species in relation to the binder (generating lower concentrations of $\mathrm{O}_{2}$ than necessary). Also, in the gas phases, it is assumed that all of the liquid AP and HTPB present on the condensed phase decompose to form gaseous species; evaporation is not included.

In this simulation, the oxygen molar fraction suffers a decrease (and cancels), according to the reactions with HTPB decomposition products, for the formation of carbon monoxide and dioxide. Also, it is interesting to highlight that in this case the carbon monoxide molar fraction suffers a decrease, because the restriction of oxidizer species makes that the oxygen presented in $\mathrm{CO}$ to be also used as oxidizing source, viewing the reactive behavior of this specie. In this simulation, the molar fractions of $\mathrm{CO}$ and $\mathrm{CO}_{2}$ are not null initially, because given the system temperature, HTPB suffers an initial decomposition that should not be discarded, generating both carbon oxides.

There is always the premise in all simulations and all studies that the materials are in a perfect state, flawless. Unfortunately, this is not the reality in most industries or laboratories, when there's low turnover. Therefore, the materials may suffer many different changes in their structure or properties. The main one is the aging process. 
The aging process is one of the most significant factors responsible for changes in the activation energy of solid propellants (usually reduction). This phenomenon can be defined as the growth of cross bonds in the polyurethane chain, altering the mechanical properties of traction resistance and elongation, in comparison of the properties just after the fabrication [9]. This aging process can be responsible for the appearance of failures and cracks in the grains, which compromise the propellant performance.

The AP/HTPB composite decomposition and the combustion mechanism have been extensively investigated in the last decades and the appearance of advanced methods of diagnostics, like flash pyrolysis, thermogravimetry and differential scanning calorimetry, led to the ressurgence of the interest. These methods are widely used for the investigation of thermal decomposition of organic materials [10], polymers [11,12], composites [13] and explosives [14].

Kissinger [15] and Ozawa [16] and Flynn [17] demonstrated that differential scanning calorimetry (DSC) technique, based on the linear relation between peak temperature and heating rate, can be used to determine the kinetics parameters of a thermal decomposition (activation energy, rate constant). The Ozawa method is one of the most popular methods for estimating activation energies by linear heating rate and it is the so-called isoconversional method. Thermal analysis cannot be used to elucidate the complete mechanism of a thermal degradation but the dynamic analysis has been frequently used to study the overall thermal degradation kinetics of polymers and composites because it gives reliable information on the frequency factor(A), the activation energy (E) and the overall reaction order [18].

In the present work, the differential scanning calorimetry (DSC) technique and the Ozawa dynamic method were used to determine the kinetic parameters of the aged and non-aged solid propellant, AP/HTPB, thermal decomposition. The Kissinger method for obtaining the activation energy value was also employed for a comparison purpose.

\section{Experimental}

\subsection{Materials and apparatus}

AP was obtained from Avibras Indústria Aeroespacial S.A.; HTPB from Petroflex Industry S.A., a subsidiary of Petrobras - Petróleo do Brasil S.A.; IPDI from Merck; DOA from Elekeiroz S.A.. The composite propellant was produced in a batch process of $5 \mathrm{~kg}$ mass (pilot plant) using a planetary mixer under vacuum atmosphere during 2 hours. All raw materials are incorporated in HTPB polyol, starting with AP that was classified to a medium size of 300 micrometers. When all ingredients are added to the HTPB polyol, the IPDI curing agent can be mixed to the liquid propellant. The propellant curing process was conducted in a temperature of 60 Celsius during a $120 \mathrm{hs}$ period time.

The synthetic aging process was conducted by exposing the cured propellant formulation to a temperature of $338 \mathrm{~K}$ for 300 days in a muffle (FNT-F3-T 6600W) that was monitored day by day during this period. 
The polyurethane network was obtained by curing HTPB polymer samples with IPDI (isophore diisocianate) at an $[\mathrm{NCO}] /[\mathrm{OH}]$ equivalent ratio of 0.95 , at $338 \mathrm{~K}$ for $120 \mathrm{~h}$. The $\mathrm{NCO} / \mathrm{OH}$ ratio is defined as the equivalent ratio between the materials containing $\mathrm{NCO}$ (IPDI) groups and those containing $\mathrm{OH}$ groups (HTPB) and it affects the mechanical properties of cured composite propellant $[13,14]$. The chemical composition of the propellant was (weight) binder $22 \%$ and others $78 \%$. The synthetic aging process was conducted by exposing the propellant formulation to a temperature of $338 \mathrm{~K}$ for 300 days.

DSC curves were obtained on a model DSC50 Shimadzu in the temperature range of 298-773 $\mathrm{K}$, under dynamic nitrogen atmosphere (ca. $50 \mathrm{~mL} / \mathrm{min}$ ). Sample masses were about $1.5 \mathrm{mg}$, and each sample was heated in hermetically sealed aluminum pans. Seven different heating rates were used for the non-aged samples: 10.0, 15.0, 20.0, 30.0, 35.0, 40.0 and $45.0 \mathrm{~K} \mathrm{~min}^{-1}$; for the aged samples, three different heat rates were used: 30,35 and $40 \mathrm{~K} \mathrm{~min}^{-1}$. DSC system was calibrated with indium (m.p. $=429.6 \mathrm{~K} ; \Delta \mathrm{H}_{\text {fus }}=28.54 \mathrm{Jg}^{-1}$ ) and zinc (m.p.= $692.6 \mathrm{~K}$ ).

\subsection{Kinetic approach}

The method used in the analysis of composite samples was based on DSC experiments in which the temperatures of the extrapolated onset of the thermal decomposition process and the temperatures of maximum heat flow were determined from the resulting measured curves for exothermic reactions. DSC curves at different heating rates, $\beta$, for non-aged and aged composite samples are shown in Figs. 4 and 5, respectively.

In order to determine the kinetic parameters of the degradation step Ozawa and Kissinger's methods were applied. They were both derived from the basic kinetic equations for heterogeneous chemical reactions and therefore have a wide application, as it is not necessary to know the reaction order [19] or the conversional function to determine the kinetic parameters. The activation energy determined by applying these methods is the sum of activation energies of chemical reactions and physical processes in thermal decomposition and therefore it is called apparent.

The temperatures of exothermic peaks, $\mathrm{T}_{\mathrm{p}}$, can be used to calculate the kinetic parameters by the Ozawa method [16,17]. These parameters are the activation energy, Ea, and the preexponential factor, A, relatives to the decomposition process.

A linear relationship between the heating rate $(\log \beta)$ and the reciprocal of the absolute temperature, $\mathrm{T}_{\mathrm{p}}{ }^{-1}$, may be found and the following linear equation can be established:

$$
\log \beta=a \cdot T_{p^{-1}}+b
$$

where $a$ and $b$ are the parameters of the linear equation: $a$ is $-0.4567 \mathrm{E} / \mathrm{R}$ (slope) and $\mathrm{b}$ is $\mathrm{a}$ constant (linear coefficient). $\mathrm{R}$ is the gas constant.

Assuming that the rate constant follows the Arrhenius law and that the exothermic reaction can be considered as a single step process, the conversion at the maximum conversion rate is invariant with the heating rate when this is linear. Having in account such assumptions, eq. 
(1) may be applied to the exothermic peak maximum temperature considering different heating rates $[15,19]$. Thus carrying out several experiments at different heating rates a plot of $\log \beta$ vs $1 / T_{p}$ may be done and the activation energy can be estimated directly from the slope of the curve using the following equation derived [14] from the eq.(1):

$$
\mathrm{Ea}=-2.19 \mathrm{R}\left[\mathrm{d} \log ß / \mathrm{d} \mathrm{T}_{\mathrm{p}^{-1}}\right]
$$

where $-\mathrm{d} \log \mathrm{B} / \mathrm{d} \mathrm{T}_{\mathrm{p}}^{-1}=$ parameter a (eq.1).

With the same above assumptions, the Kissinger method ${ }^{8}$ may be used to calculate the activation energy and the pre-exponential factor from the maximum rate condition which will occur at the maximum exothermic peak temperature, $T_{p}$.

The Kissinger method is based on the plot of $\ln \left(\beta / T_{p}{ }^{2}\right)$ vs. $1 / T_{p}$. Activation energy is calculated from the slope of the curve using the following equation:

$$
\mathrm{Ea}=\mathrm{R} d\left[\ln \beta / \mathrm{T}_{\mathrm{p}}^{2}\right] /\left[\mathrm{d}\left(1 / \mathrm{T}_{\mathrm{p}}\right)\right]
$$

Once time $\mathrm{E}$ is known the values of pre-exponential factor, $\mathrm{A}$, are calculated with the equation:

$$
\mathrm{A}=\left(\beta \mathrm{E} \exp \mathrm{Ea} / \mathrm{RT}_{\mathrm{p}}\right) / \mathrm{RT}_{\mathrm{p}}{ }^{2}
$$

The temperature dependence of the specific rate constant $\mathrm{k}$ is described by the Arrhenius equation:

$$
\mathrm{k}=\mathrm{A} \exp \left(-\mathrm{Ea} / \mathrm{RT}_{\mathrm{p}}\right)
$$

The kinetic Shimadzu software, based on the Ozawa method, feed with the exothermic peak temperatures and the heating rate data, gives the Arrhenius kinetic parameters (Ea, A) relative to the thermal decomposition of composite and, consequently, with the eq. (5) the overall rate constant can be calculated.

There's also a possibility of using Flynn and Wall methodology with TGA analysis (constant heating rate TGA) [17], once it requires less experimental time, although this method is limited to single-step decompositions and first order kinetics. The approaches are the following:

This first approach requires at least three determinations at different heating rates (Fig. 4 below), following the Arrhenius equation:

$\left(\frac{d \alpha}{d t}\right)=A \cdot \exp \left(\frac{-E \alpha}{R T}\right)(1-\alpha)^{n}$, where $\alpha$ represents the fraction of decomposition and $n$ is the reaction order.

Re-arranging, the equation turns to:

$E \alpha=\left(\frac{-R}{c}\right) \frac{d \ln \beta}{d\left(\frac{1}{T}\right)}$, where $\mathrm{c}$ is a constant for $\mathrm{n}=1$. 


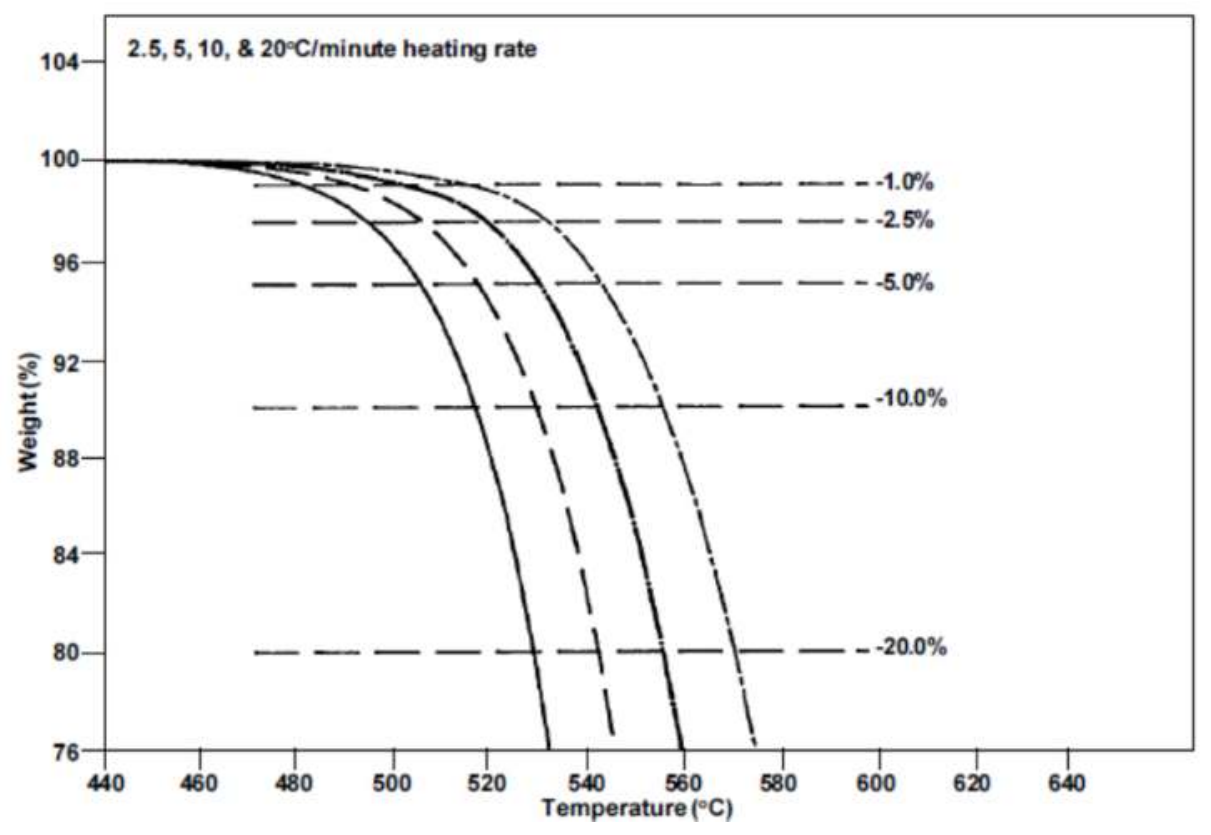

Figure 4. Constant heating rate TGA plots - Flynn \& Wall method [20]

From this curve is possible to construct a $\ln \beta$ vs $1 / T$ plot. The slope of this new curve is used to calculate the activation energy.

\section{Results and discussion}

The activation energy and kinetic parameters of thermal decomposition of propellant samples were calculated by Ozawa method using DSC curves at different heating rates: 10.0, 15.0, 20.0, 30.0, 35.0, 40.0 and $45.0 \mathrm{~K} \mathrm{~min}^{-1}$ for the non-aged ones and 30.0, 35.0 and $40.0 \mathrm{~K}$ $\mathrm{min}^{-1}$ for the aged ones. 


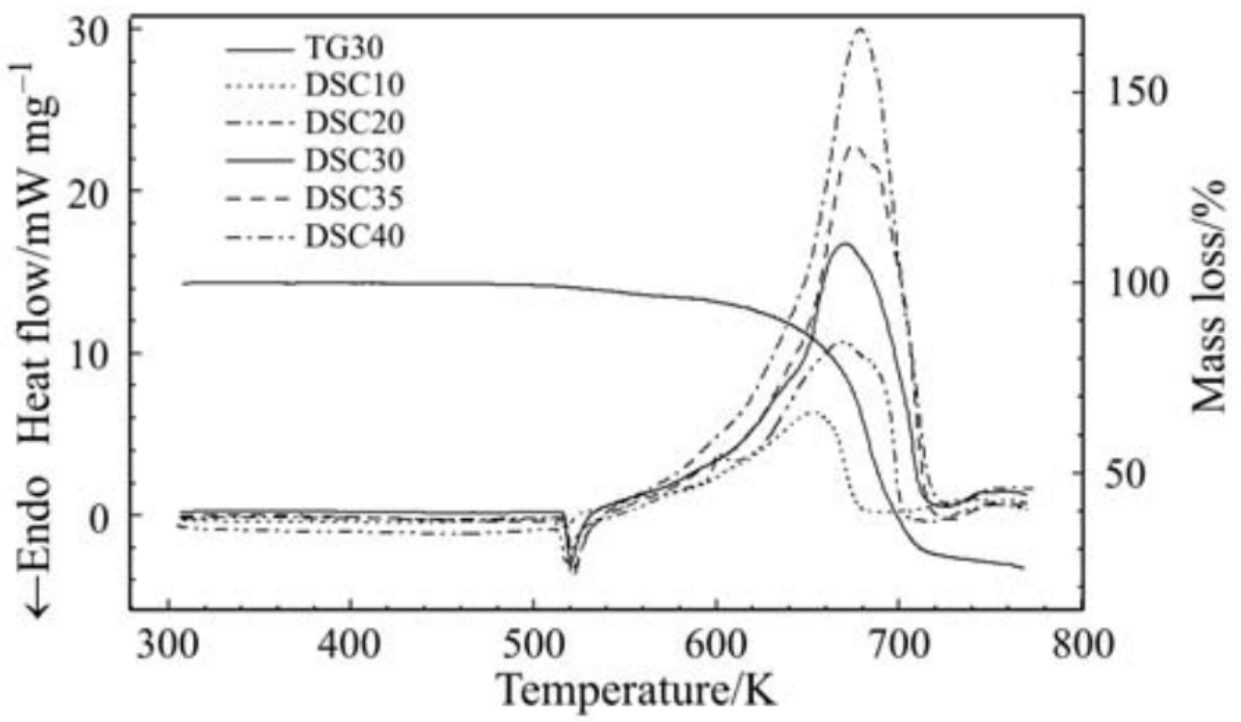

Figure 5. DSC curves of thermal decomposition of non-aged composite samples, $\mathrm{AP} / \mathrm{HTPB}$, at the heating rates: 10, 20, 30, 35 and $40 \mathrm{~K} \mathrm{~min}^{-1}$ and TG curve with a heating rate of $30 \mathrm{~K} \mathrm{~min}^{-1}$

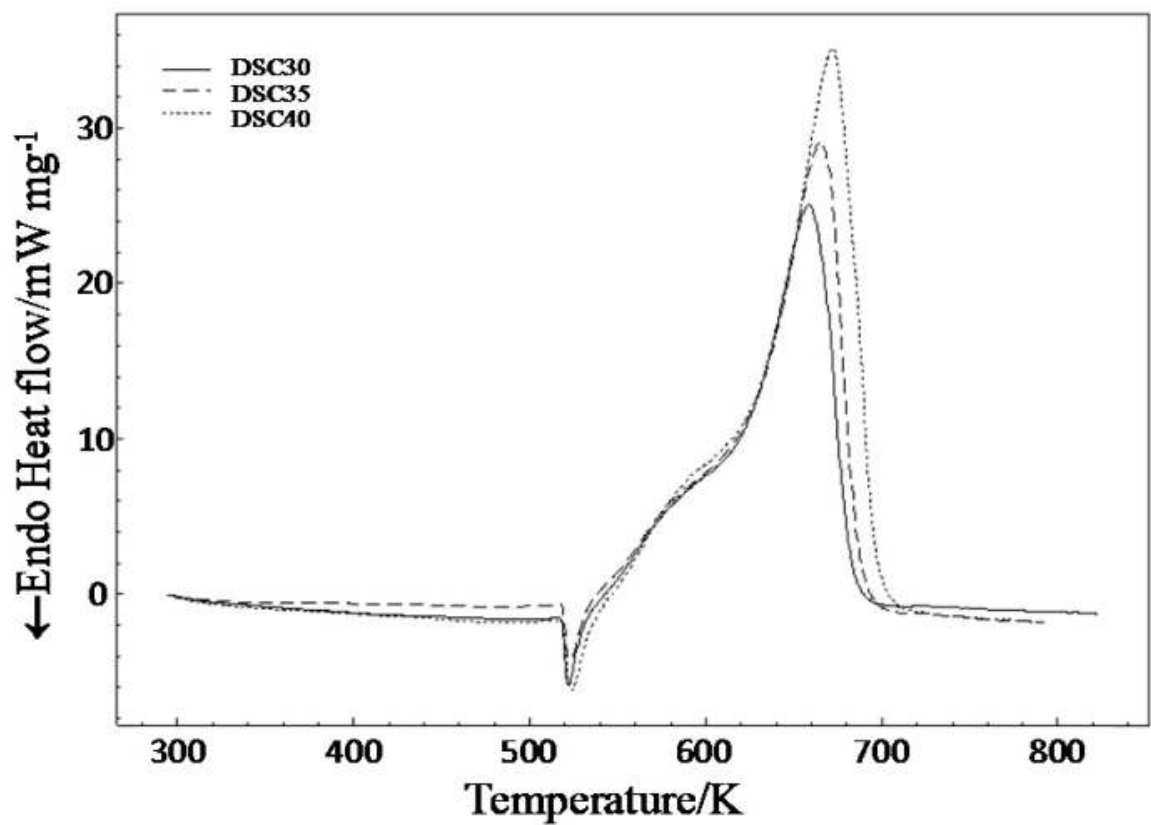

Figure 6. DSC curves of thermal decomposition of aged composite samples, AP/HTPB, at the heating rates: 30,35 and $40 \mathrm{~K} \mathrm{~min}^{-1}$ 
The exothermic events have different maximum temperatures in both cases; the higher the heating rate, higher is the maximum temperature of the peak.

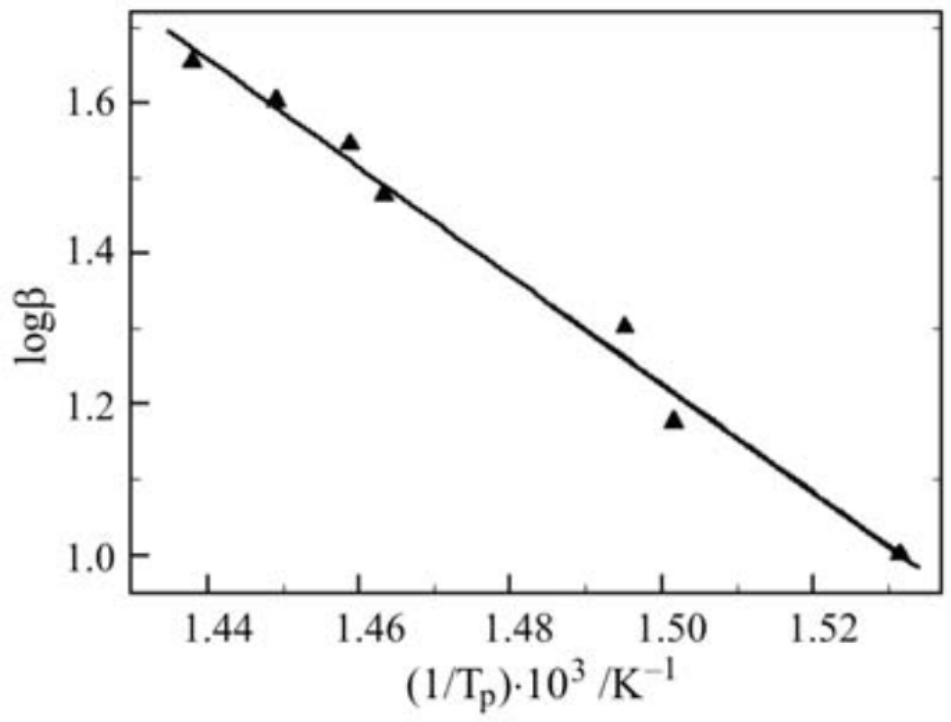

Figure 7. Ozawa plot for AP/HTPB samples at 10, 15, 20, 30, 35, 40 and $45 \mathrm{~K} \mathrm{~min}^{-1}$

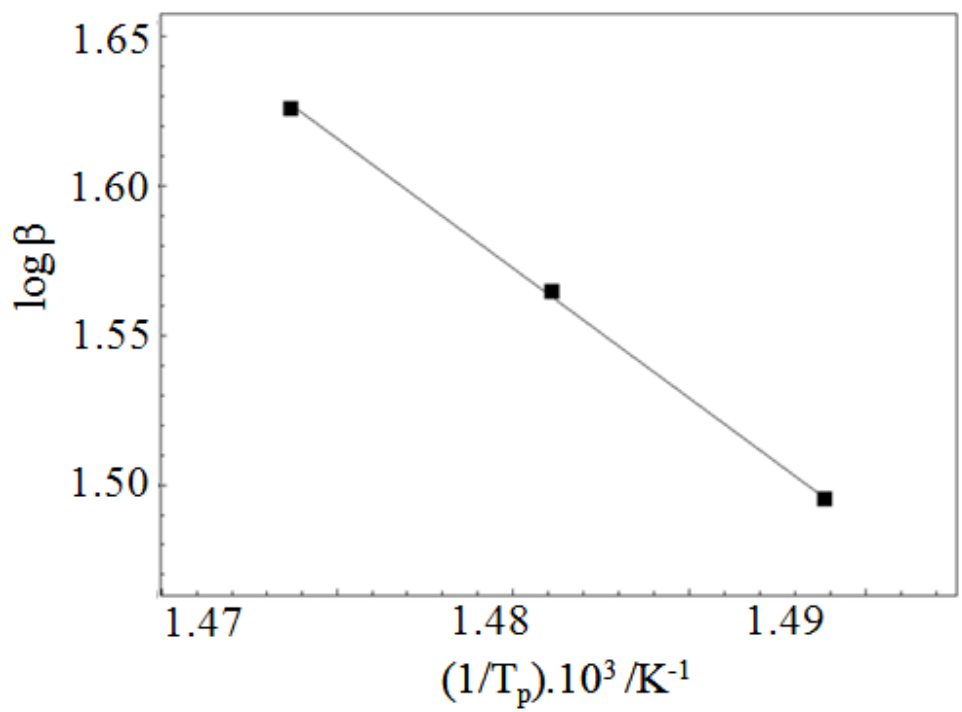

Figure 8. Ozawa plot for aged AP/HTPB samples at 30,35 and $40 \mathrm{~K} \mathrm{~min}^{-1}$ 
The DSC curves are presented in Figs. 5 and 6. The DSC curves show that the first stage is endothermic and the second stage is exothermic. The endothermic event is quite similar for the different heating rates used and it shows the same peak temperature. This event occurs around $520 \mathrm{~K}$ and it was not considered because it represents a phase transition of ammonium perchlorate (AP) from the orthorhombic to the cubic form [21,22]. Together with DSC curves obtained for different heating rates (non-aged samples), Fig. 1, the TG curve for $30.0 \mathrm{~K} \mathrm{~min}^{-1}$ was included to show that in the region corresponding to the endothermic peak (DSC curves) there is no any weight loss or, at least, it is imperceptible and, the same behavior was observed in all of other TG curves for different heating rates.

Figures 7 and 8 show the plot of $\log \beta$ vs the reciprocal of the absolute temperature relative to each maximum of the exothermic stage. The values of the activation energy were found to be $134.5 \mathrm{~kJ} \mathrm{~mol}^{-1}$ (non-aged samples) and $79.0 \mathrm{~kJ} \mathrm{~mol}^{-1}$ (aged samples). Sell et al.[23] using thermogravimetry at heating rates between 0.5 and $10 \mathrm{~K} \mathrm{~min}^{-1}$ studied the decomposition kinetics of the AP/HTPB propellant samples with isoconversional method and the calculated activation energies are between 100 and $230 \mathrm{~kJ} \mathrm{~mol}^{-1}$.

From the slope of Kissinger plot $\left(\ln \left(\beta / \mathrm{T}_{\mathrm{p}}{ }^{2}\right)\right.$ vs. $\left.1 / \mathrm{T}_{\mathrm{p}}\right)$ and eq. (3) the activation energy was also calculated and is $126.2 \mathrm{~kJ} \mathrm{~mol}^{-1}$ for the non-aged samples, therefore quite similar to that obtained using the Ozawa method.

The thermal decomposition of solid composite propellant is a multistep process and the reaction mechanism changes with the temperature and, consequently, the activation energy varies with the extent of the reaction. DSC data are used to estimate the activation energies of thermal decomposition of propellant samples because the global decomposition reaction is taken in account. Implicit in any discussion about the decomposition is the fact that the overall process is complex, and any derived rate parameters do not correspond to an elementary single step. TG/DTG results are in agreement with this assumption.

The pre-exponential factor was found to be $2.0410^{10} \mathrm{~min}^{-1}$ (non-aged samples) and $1.29 .10^{6}$ $\mathrm{min}^{-1}$ (aged samples) and the reaction orders for the global composite decomposition were estimated in 0.7 (non-aged) and 0.6 (aged) by the kinetic Shimadzu software based in the Ozawa method. This value is quite different from the Arrhenius assumption where the reaction order is always considered as 1.0. For practical purposes the Arrhenius parameters, like the corrected reaction order, can be used to estimate the overall rate constant (k) for thermal decomposition using the eq. (5).

The differences found in the kinetics parameters between the original and the aged samples, specially the activation energy (Ea), confirm the practical observation that energetic materials like the composites used in solid propellant rocket motors require less energy to start the combustion process as they age. Besides, considering the heating rate of $40 \mathrm{~K} \mathrm{~min}^{-1}$ for the original and for the aged samples, a reduction in the enthalpy of the decomposition's exothermic phase was observed (2.56 to $\left.1.15 \mathrm{~J} \mathrm{~g}^{-1}\right)$. 
Cohen [24] studied the kinetics of the surface pyrolysis of HTPB and, assuming zero-order kinetics, they found the activation energy of $71 \mathrm{~kJ} \mathrm{~mol}^{-1}$. Comparison between the activation energies for the propellant decomposition and the activation energies for decomposition of individual ammonium perchlorate (AP) or/and HTPB binder suggests that the overall kinetics of the mass loss is determined by the reaction between the binder and the decomposition products of AP [24].

Ammonium perchlorate is widely used as an oxidizer in energetic composites and it is one of the most important raw materials in propellant formulations where it represents at least $80 \%$ of total mass of composite solid propellants, so its contribution on the thermal decomposition behavior of propellant samples is always very important. The addition of burning rates catalysts like $\mathrm{Fe}_{2} \mathrm{O}_{3}$ on the propellant formulation alters the thermal decomposition behavior of $\mathrm{AP}$, and consequently the thermal decomposition behavior of the propellant. Shin-Ming [22] showed that the presence of these catalysts compounds reduce the maximum decomposition reaction temperature in AP samples.

Another important aspect of DSC curves is the correlation of maximum temperature of exothermic peak obtained for each heating rate applied to the composite sample during the experiments. This correlation can be used to determine the burning rate characteristics of a composite solid propellant with a specific formulation. The burning rate characteristics are an important ballistic parameter of the energetic composite like solid propellant. Xiao-Bin [25] showed that the burning rates of propellants were very closely related to the exothermic peak temperature of ammonium nitrate (AN) that is used as an oxidizer in smokeless propellant formulation.

In the present work, the DSC curves at different heating rates were obtained for original and synthetically aged samples that have the same raw materials and with the same manufacture process. These conditions are necessary because differences in the raw materials, as ammonium perchlorate (AP) particle size, can affect the thermal decomposition behavior of the composite. In other words, the decomposition mechanism of AP powder of fine particle size differs that of AP of larger particle size.

\section{Conclusions}

For energetic materials like composite solid propellant, it is critical to use the minimum sample size and low heating rates to avoid the risks to potential damage of the DSC cell resulting in DSC curves with a lot of interferences caused by the detonation behavior of composite samples. In opposition to this criteria, in this study, high heating rates were used (10.0 to $\left.45.0 \mathrm{~K} \mathrm{~min}^{-1}\right)$, but to compensate this condition very low sample sizes were used $(\approx$ $1.5 \mathrm{mg}$ ). Despite these heating rates are not close to the rocket motor chamber conditions (heating rates estimated as $10^{6} \mathrm{~K} \mathrm{~s}^{-1}$ ) the slower heating rates used in this work allow one to get a better insight into the reaction kinetics mechanisms. 
The Ozawa and Kissinger methods demonstrated that differential scanning calorimetry technique, based on the linear relation between peak temperature and heating rate, can be used to determine the kinetics parameters of thermal decomposition reaction of energetic materials giving reproducible results.

The DSC curves do not show any interference and the kinetic data obtained using the maximum temperatures (reciprocal, in $\mathrm{K}^{-1}$ ) and the respective heating rates are very close to the results found in the literature, at very lower heating rates [26-29].

\section{Author details}

R. F. B. Gonçalves, J. A. F. F. Rocco and K. Iha

Instituto Tecnológico de Aeronáutica, CTA, São José dos Campos, S.P., Brasil

\section{Acknowledgement}

The authors gratefully acknowledge financial support from FAPESP (Fundação de Amparo à Pesquisa do Estado de São Paulo) and CNPq (Conselho Nacional de Desenvolvimento Científico e Tecnológico) for the fundings and investiments.

\section{References}

[1] Brill T B, Budenz B T (2000) Flash Pyrolysis of Ammonium Perchlorate-HydroxylTerminated-Polybutadiene Mixtures Including Selected Additives, Progress in Astronautics and Aeronautics, AIAA, Vol.185, pp. 3.

[2] Beckstead M W, Puduppakkam K, Thakre P, Yang V (2007) Progress in Energy and Combustion Science, 33, 497.

[3] Boggs T L (1970) AIAA Journal, 8, 5, 867.

[4] Beckstead M W, Puduppakkam K V (2004) Modeling and Simulation of Combustion of Solid Propellant Ingredients Using Detailed Chemical Kinetics, 40th AIAA/ASME/SAE/ASEE Joint Propulsion Conference and Exhibit.

[5] Kubota N (2002) Propellants and Explosives, Wiley-VCH.

[6] Gross M L (2007) Two-dimensional modeling of AP/HTPB utilizing a vorticity formulation and one-dimensional modeling of AP and ADN.

[7] Gonçalves R F B, Rocco J A F F, Machado F B C, Iha K (2012) Ammonium perchlorate and ammonium perchlorate-hydroxyl terminated polybutadiene simulated combustion, Journal of Aerospace Technology and Management, v 4, n1.

[8] Korobeinichev O, Ermolin N, Chernov A, Emel'yanov I (1990) AIAA/SAE/ASME/ASEE 26th Joint Propulsion Conference.

[9] Celina M, Minier L, Assink, R (2002) Development and application tool characterize the oxidative degradation of $\mathrm{AP} / \mathrm{HTPB} / \mathrm{Al}$ propellants in a propellant reability study, Thermochimica Acta, Vol. 384, pp. 343, 349. 
[10] Mathot V B F (2001) New routes for thermal analysis and calorimetry as applied to polymeric systems, J. Therm. Anal. Cal., Vol. 64, pp. 15, 35.

[11] Maijling J, Simon P, Khunová V (2002) Optical Transmittance Thermal Analysis of the Poly(Ethylene Terephtalate) Foils, J. Therm. Anal. Cal., Vol. 67, pp. 201, 206.

[12] de Klerk W P C, Schrader, M A, van der Steen A C (1999) Compatibility Testing of Energetic Materials, Which Technique?, J. Therm. Anal. Cal., Vol. 56, pp. 1123, 1131.

[13] Stankovic M, Kapor V, Petrovic S (1999) The Thermal Decomposition of Triple-Base Propellants, J. Therm. Anal. Cal., Vol. 56, pp. 1383-1388.

[14] Jones D E G, Feng H T, Augsten R A, Fouchard R C (1999) Thermal Analysis Studies on Isopropylnitrate, J. Therm. Anal. Cal., Vol. 55, pp, 9, 19.

[15] Kissinger H E (1957) Reaction Kinetics in Differential Thermal Analysis, Anal. Chem., Vol. 29, pp. 1702.

[16] Ozawa T, Isozaki H, Negishi A (1970) A new type of quantitative differential analysis, Thermochimica Acta., Vol. 1, No. 6, pp. 545, 553.

[17] Flynn J H (1966) A quick, direct method for the determination of activation energy from thermogravimetric data, Thermochim. Acta, Vol. 4, pp. 323.

[18] Park J W, Lee H P, Kim H T, Yoo K O (2000) A kinetic analysis of thermal degradation of polymers using a dynamic method, Polym. Degrad.Stabil., Vol. 67, pp. 535.

[19] Ozawa T (2001) Temperature control modes in thermal analysis, J. Therm. Anal. Cal., Vol. 64, 2001, pp. 109, 126.

[20] Sauerbrunn S, Gill P, Decomposition Kinetics using TGA, TA Instruments.

[21] Na-Lu L, Tsao-Fa Y (1991) The thermal behavior of porous residual ammonium percholate, Thermochim. Acta, Vol. 186, pp. 53.

[22] Shin-Ming S, Sun-I C, Bor-Horng W (1993) The thermal decomposition of ammonium perchlorate (AP) containing a burning-rate modifier, Thermochim. Acta, Vol. 223, pp. 135.

[23] Sell T, Vyazovkin S, Wight C A (1999) Thermal decomposition kinetics of PBAN-Binder and composite solid rocket propellants, Combust. Flame, Vol. 119, pp. 174.

[24] Cohen N S, Fleming R W, Derr R L (1974) Role of binders in solid propellant combustion, AIAA Journal, Vol. 6, pp. 212.

[25] Xiao-Bin Z, Lin-Fa H, Xiao-Ping Z (2000) Thermal decomposition and combustion of GAP/NA/Nitrate Ester propellants, Progress in Astronautics and Aeronautics, AIAA, Vol. 185, pp. 413.

[26] Du T (1989) Thermal decomposition studies of solid propellant binder HTPB, Thermochim. Acta, Vol. 138, pp. 189.

[27] Rocco J A F F, Lima J E S, Frutuoso A G, Iha K, Ionashiro M, Matos J R, Suárez-Iha M E V (2004) Thermal degradation of a composite solid propellant examined by DSC Kinetic study, J. Therm. Anal. Cal., Vol. 75, pp. 551, 557. 
[28] Andrade J, Frutuoso A G, Iha K, Rocco J A F F, Bezerra E M, Matos J R, Suárez-Iha M E V (2008) Estudo da decomposição térmica de propelente sólido compósito de baixa emissão de fumaça, Quim. Nova, Vol. 31, No. 2, pp. 301-305.

[29] Andrade J, Iha K, Rocco J A F F, Bezerra E M (2007) Análise térmica aplicada ao estudo de materiais energéticos, Quim. Nova, Vol. 30, No. 4, pp. 952, 956. 